\title{
Prepubertal growth rate of Bali cattle and its crosses with Simmental breed at lowland and highland environment
}

\author{
L. Wira Pribadi ${ }^{1 *}$, Sucik Maylinda ${ }^{2}$, Moch. Nasich ${ }^{2}$, S. Suyadi ${ }^{2}$ \\ ${ }^{1}$ Student of Doctoral Program in Animal Science, Post Graduate Program of Animal Husbandry Faculty, \\ Brawijaya University, Malang, Indonesia \\ ${ }^{2}$ Departemen of Animal Production, Faculty of Animal Husbandry, Brawijaya University, Jalan Veteran Malang, \\ Indonesia 65145.
}

\begin{abstract}
Prepubertal growth rate $(G R-1,2)$ of Bali cattle and its crosses with Simmental breed in the hot environment of lowland $(0-100 \mathrm{~m})$ and the cool environment of highland (700-1100 m above sea level) of West Nusa Tenggara province, Indonesia, were evaluated by measuring the birth weight $(B W), 150 d$ weaning weight (WW.150), preweaning growth rate (GR-1), yearling weight $(Y W)$, and post weaning growth rate (GR-2) of 187, 166, 216, and 156 calves for Bali breed (B), Bali x Simmental crossbred (SB), SB x Simmental back crossed (SBS), and $S B \times$ Bali back crossed (SBB), respectively. The results showed, GR-1,2 of the calf were significantly different between $B$ calves and the crosses, and between the two altitudes of farms for the crosses calves. The $B$ calves were found to have an average $0.29 \mathrm{~kg} /$ day GR-1,2 which was not different between raised in the lowland and highland environment. The crosses calves grew 75.02, 60.71, and 82.14\% faster than those of B calf in the lowland for SB, $S B S$, and $S B B$ calves, respectively, and $83.55,115.48$, and $70.97 \%$ faster than those of $B$ calf in the highland for $S B$, $S B S$, and $S B B$ calves, respectively.
\end{abstract}

Key words: Bali cattle, Simmental, crossbred, prepubertal growth, altitudes

\section{Introduction}

Currently, almost $75 \%$ of world cattle population resides in tropical zones, however, animal production in these areas is often hampered by low genetic progress, lack of record keeping and reduced availability of scientific literature [1]. Thereby, information on productive performance of cattles in the tropics is lacking.

One of the important cattle breed in the tropical countries is Bali cattle. This cattle are an indigenous cattle in Indonesia, originated from Banteng (Bibos banteng) which is well known as Bos sondaicus. Bali cattle are one of the important beef cattle breeds contributing to the development of livestock industries in Indonesia, and are the most predominant genotype within the eastern island, e.g. in West Nusa Tenggara province. The majority of these cattle are maintained traditionally, therefore, their growth performance is considered to be low. However, comparing to other breeds, Bali cattle have better adaptation abilities especially in marginal environment [2], have high meat quality and low fat percentage [3], have high fertility and give birth each year constantly over a long time [4], and have high heterosis effect in crossbred [5].

The effort to increase productivity of Bali cattle in some areas made use of crossbreeding with exotic breeds of Bos taurus such as Simmental, Limousine, Hereford, and Charolais, and Brahman cattle (Bos indicus), in which Simmental was suggested the most one [6]. Crossbreeding systems are used in beef cattle production to take advantage of heterosis (non-additive effects) and to exploit breed differences for specific characteristics (additive effects) to improve performance and value of the progeny [7], under different environmental conditions [8]. However, this effort may have negative impacts as it was not followed by production environment improvements, due to genotype-environment interactions. Replacing indigenous with exotic breed in South East Asia might in fact create significant problem, e.g. distocia because of heterosis increasing calf birth weight, low tolerance on harsh environment condition, and increase work to feed each animal because of higher growth and greater size at maturity [9]. Therefore, it is important to evaluate factors influencing economically traits in a diversity of environment in order to understand the production environment while making management decisions in a crossbreeding system, since interactions may influence productive efficiency.

Thermal elements of the environment such as air temperature and humidity were the most importance aspects of cattle production environment, because of their direct effects on productivities $[10,11]$. In the tropical countries, the thermal environment was varied by altitude [12, 13]. Indeed, low altitude (lowland) existing as hot environment, while the high altitude (highland) as cold environment. 
Prepubertal growth rate of Bali cattle and its crosses with Simmental breed at lowland And ....

Effect of that environmental factors on calf growth during prepubertal period such as preweaning and postweaning growth have not been adequately examined. Growth traits such as weight at birth, weaning, and yearling are of primary economical importance in cow-calf production system. The birth and weaning weight are known to be influenced by the direct genetic effect of the calf and the maternal genetic effect [14].

The primary goal of animal breeders is to maximize the rate of genetic improvement. Weaned and yearling calves are the major product of beef cows, their weight has a great influence on returns from sales and hereby on the economy and profitability of beef cattle production. Moreover, the weaning and yearling weight of calf are important performance and breeding criterion for beef cattle $[15,1]$.

Performances of a breed or crossbred cattles are not expected to be the same under all environments. The breed and crossbred together should be evaluated under a variety of environmental conditions. Hence, the objective of this study was to investigate prepubertal growth of Bali cattle and its crosses with Simmental breed under hot environment of lowland and cold environment of highland areas in West Nusa Tenggara province, Eastern Part of Indonesia.

\section{Materials and Methods}

This study was carried out in the small-holder farms of cattle production which spread at two different altitude areas i.e. lowland $(0-100 \mathrm{~m})$ and highland $(700-1000 \mathrm{~m}$ above sea level) areas of West Nusa Tenggara province, eastern part of Indonesia. These two different altitude areas showed average daily temperature, relative humidity, and temperature-humidity index (THI) of $31.66{ }^{\circ} \mathrm{C}, 65.89 \%$, and 80.02 for lowland, and $24.52{ }^{\circ} \mathrm{C}$, $87.55 \%$, and 69.40 for highland areas, respectively.

There were 731 normally birth and healthy calves observed, consisting of Bali breed (B), Bali x Simmental crossbred (SB), SB x Simmental back crossed (SBS), and SB x Bali back crossed (SBB). All of the calves were taken purposively from those of birth within rainy season of January to May 2013 in those two different altitude of farms . Detail number of calves observed considering genotype, sex, and location (altitude), are provided in Table 1.

Table 1. Number of observation by genotype, sex, and altitude for birth to yearling weight

\begin{tabular}{|c|c|c|c|c|}
\hline \multirow[b]{2}{*}{ Genotype of calves } & \multirow[b]{2}{*}{ Sex } & \multicolumn{2}{|c|}{ Altitude } & \multirow[b]{2}{*}{ Total } \\
\hline & & Lowland & Highland & \\
\hline \multirow[t]{2}{*}{ Bali (B) } & Male & 52 & 44 & 96 \\
\hline & Female & 50 & 41 & 91 \\
\hline \multirow[t]{2}{*}{ B x Simmental (SB) } & Male & 40 & 51 & 91 \\
\hline & Female & 40 & 35 & 75 \\
\hline \multirow[t]{2}{*}{ SB x Simmental (SBS) } & Male & 54 & 45 & 99 \\
\hline & Female & 65 & 52 & 117 \\
\hline \multirow[t]{3}{*}{ SB x Bali (SBB) } & Male & 43 & 39 & 82 \\
\hline & Female & 33 & 41 & 74 \\
\hline & Overall & 382 & 349 & 731 \\
\hline
\end{tabular}

Birth weight (BW), weaning weight in 150 days (WW.150), preweaning growth (GR-1), yearling weight $(\mathrm{YW})$, and post weaning growth rate (GR-2) of the calves were measured directly in order to evaluate the prepubertal growth rate (GR-1,2). The birth weight of the calves was taken within $24 \mathrm{~h}$ after calving, while the calves were allowed to suckle on their dams until weaning. The weaning weight was taken when the calves weaned within age of 4-6 months or in average of five months old (150 days). In all cases the weaning weight was then corrected to 150 days (WW.150) using a following equation:

$$
\mathrm{WW} .150=\mathrm{BW}+\frac{\text { Actual WW }-\mathrm{BW}}{\text { Age (days) at weaning }} \times 150 \times \text { Cow Age Correction Factor }
$$

where, the correction factor referred to Indonesian local cows (Hardjosubroto, 1994) in which 1.15, 1.10, 1.05, and 1,00 for 2, 3, 4, and $>5$ years old cows, respectively. Yearling weight was taken in 365 days age of the calves. Then, prepubertal growth rate of the calves were analyzed in accordance to average daily weight gains obtained.

Data were arranged by genotype of calf and location (altitude) of farms. Then, Analysis of Variance (ANOVA) and mean comparisons with Least Significance Difference (LSD) test were performed using SPSS program considering genotype, location, and genotype $\mathrm{x}$ location effects. 


\subsection{Preweaning growth}

\section{Results}

Preweaning growth rate is measured as daily weight gain recorded from birth to weaning. The values were, however, determined by both birth weight and weaning weight of the calves. The mean weight of calf at birth (BW) and weaning (WW.150), and preweaning growth rate (GR-1) of Bali cattle and its crosses with Simmental breed at different altitude of farms are provided in Table 2. Then, growth response of genotypes on the altitudes of farms is presented in Figure 1. The results indicated, that BW, WW.150, and GR-1 were affected $(\mathrm{P}<0.05)$ by genotype of calves and altitude of farms.

Crosses calves (SB, SBS, and SBB) showed higher BW, WW.150, and GR-1 than those of Bali calves (B), which increased as Simmental proportion of the genotype was increase. In contrast, Bali breed restricted the BW and WW.150 of the crosses calves. The average BW, WW.150, and GR-1 of 28.64, 106.16, and $0.52 \mathrm{~kg}$ for the crosses calves were $69.27,71.34$, and $73.33 \%$ higher than those of $16.92,61.96$, and $0.30 \mathrm{~kg}$ for B calves.

There were an increase in BW, WW.150, and GR-1 for the crossed calves from lowland to highland, in which genotype with larger proportion of Simmental showed higher increasing index. While, that of B calves showed that BW and GR-1 were not influenced by the altitude, but their WW.150 in highland was $12.63 \%$ higher than that in lowland. The average BW, WW.150, and GR-1 of 27.61, 94.37, and $0.45 \mathrm{~kg}$ for the crossed calves in lowland were $7.50,24.98$, and $33.30 \%$ lower than $29.68,117.95$, and $0.60 \mathrm{~kg}$ in highland.

Table 2. Preweaning performance of Bali (B) cattle and its crosses with Simmental (S) breed at the different altitudes of farms

\begin{tabular}{ccccc}
\hline $\begin{array}{c}\text { Altitude of } \\
\text { farms } \\
\text { (above sea levels) }\end{array}$ & $\begin{array}{c}\text { Genotype } \\
\text { of calf }\end{array}$ & $\begin{array}{c}\text { Birth weight } \\
(\mathrm{BW}), \mathrm{kg}\end{array}$ & $\begin{array}{c}\text { Weaning weight } 150 \text { days } \\
(\text { WW.150), kg }\end{array}$ & $\begin{array}{c}\text { Preweaning growth rate } \\
(\mathrm{GR}-1), \mathrm{kg} / \mathrm{day}\end{array}$ \\
\hline Lowland & $\mathrm{B}$ & $16.57 \pm 1.00^{\mathrm{a}}$ & $68.28 \pm 3.15^{\mathrm{a}}$ & $0.34 \pm 0.05^{\mathrm{a}}$ \\
$(0-100 \mathrm{~m})$ & $\mathrm{SB}\left(1 / 2 \mathrm{~B}^{1} / 2 \mathrm{~S}\right)$ & $27.89 \pm 1.98^{\mathrm{b}}$ & $105.65 \pm 5.27^{\mathrm{b}}$ & $0.53 \pm 0.08^{\mathrm{b}}$ \\
& $\mathrm{SBS}\left(1 / 4 \mathrm{~B}^{3} / 4 \mathrm{~S}\right)$ & $31.78 \pm 1.77^{\mathrm{c}}$ & $99.44 \pm 9.89^{\mathrm{c}}$ & $0.46 \pm 0.08^{\mathrm{c}}$ \\
& $\mathrm{SBB}\left(3 / 4 \mathrm{~B}^{\mathrm{c}} / 4 \mathrm{~S}\right)$ & $23.15 \pm 1.56^{\mathrm{d}}$ & $90.02 \pm 9.62^{\mathrm{d}}$ & $0.44 \pm 0.06^{\mathrm{c}}$ \\
Highland & $\mathrm{B}$ & $17.26 \pm 1.59^{\mathrm{a}}$ & $73.64 \pm 4.52^{\mathrm{e}}$ & $0.37 \pm 0.06^{\mathrm{a}}$ \\
$(700-1.000 \mathrm{~m})$ & $\mathrm{SB}(1 / 2 \mathrm{~B} \mathrm{~B} / 2 \mathrm{~S})$ & $30.55 \pm 1.99^{\mathrm{c}}$ & $121.67 \pm 16.18^{\mathrm{f}}$ & $0.61 \pm 0.10^{\mathrm{d}}$ \\
& $\mathrm{SBS}\left(1 / 4 \mathrm{~B}^{\mathrm{b}} / 4 \mathrm{~S}\right)$ & $33.75 \pm 1.83^{\mathrm{e}}$ & $139.92 \pm 17.27^{\mathrm{g}}$ & $0.72 \pm 0.12^{\mathrm{e}}$ \\
\hline
\end{tabular}

Note: Means in the same column with different superscripts is differ significantly $(\mathrm{P}<0.05)$

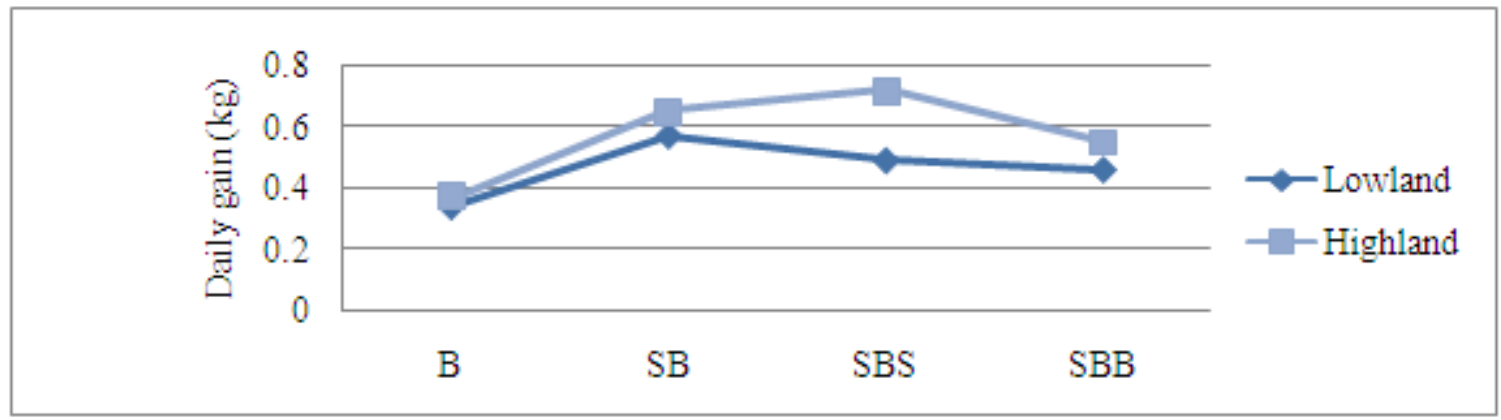

Fig. 1. Preweaning growth response of genotypes on the different altitude

\subsection{Post weaning growth}

Post weaning growth rate was measured as daily weight gain recorded from weaning to yearling. The values were, however, determined by both weaning weight and yearling weight of the calves. Table 3 showed the effects of genotype of calves and altitude of farms on yearling weight (YW) and post weaning growth (GR-2) of Bali cattle and its crosses with Simmental breed at different altitudes of farms. Both YW and GR-2 were affected by genotype of calves $(\mathrm{P}<0.01)$ and altitude of farms $(\mathrm{P}<0.05)$.

The average YW and GR-2 for B calves were obtained $125.85 \mathrm{~kg}$ and $0.29 \mathrm{~kg} / \mathrm{day}$, respectively. They were, however, much lower than the average of $231.68 \mathrm{~kg}$ and $0.62 \mathrm{~kg} /$ day for the crosses calves. The mean post weaning growth rate (GR-2) of $0.29 \mathrm{~kg} / \mathrm{day}$ for B calf in the lowland was not different to that of $0.30 \mathrm{~kg} / \mathrm{day}$ in highland environment (Figure 2). However, the crosses calves in the lowland showed lower GR-2 than those in 
Prepubertal growth rate of Bali cattle and its crosses with Simmental breed at lowland And ....

highland, in which SBS calf as a genotype with the largest proportion of Simmental grew slowest $(0.41 \mathrm{~kg} / \mathrm{day})$ in this environment but fastest $(0.75 \mathrm{~kg} / \mathrm{day})$ in the highland environment.

Table 3. Post weaning performance of Bali cattle and its crosses with Simmental breed at the different altitudes of farms

\begin{tabular}{cccc}
\hline $\begin{array}{c}\text { Altitude of farms } \\
\text { (above sea levels) }\end{array}$ & $\begin{array}{c}\text { Genotype } \\
\text { of calf }\end{array}$ & $\begin{array}{c}\text { Yearling weight } \\
(\mathrm{YW}), \mathrm{kg}\end{array}$ & $\begin{array}{c}\text { Post weaning growth rate } \\
(\mathrm{GR}-2), \mathrm{kg} / \mathrm{day}\end{array}$ \\
\hline & $\mathrm{B}$ & $121.79 \pm 23.66^{\mathrm{a}}$ & $0.27 \pm 0.03^{\mathrm{a}}$ \\
Lowland & $\mathrm{SB}\left(1 / 2 \mathrm{~B}^{1 / 2 \mathrm{~S}}\right)$ & $200.43 \pm 21.52^{\mathrm{b}}$ & $0.44 \pm 0.05^{\mathrm{b}}$ \\
$(0-100 \mathrm{~m})$ & $\mathrm{SBS}\left(1 / 4 \mathrm{~B}^{3} / 4 \mathrm{~S}\right)$ & $203.89 \pm 24.71^{\mathrm{b}}$ & $0.41 \pm 0.03^{\mathrm{bc}}$ \\
& $\mathrm{SBB}(3 / 4 \mathrm{~B} 1 / 4 \mathrm{~S})$ & $178.71 \pm 17.68^{\mathrm{c}}$ & $0.38 \pm 0.04^{\mathrm{c}}$ \\
& & & $0.30 \pm 0.09^{\mathrm{a}}$ \\
& $\mathrm{B}$ & $139.92 \pm 22.98^{\mathrm{d}}$ & $0.51 \pm 0.05^{\mathrm{d}}$ \\
Highland & $\mathrm{SB}\left(1 / 2 \mathrm{~B}^{1 / 2} \mathrm{~S}\right)$ & $230.98 \pm 30.23^{\mathrm{e}}$ & $0.65 \pm 0.10^{\mathrm{e}}$ \\
& $\mathrm{SBS}\left(1 / 4 \mathrm{~B}^{3} / 4 \mathrm{~S}\right)$ & $289.53 \pm 22.42^{\mathrm{f}}$ & $0.47 \pm 0.08^{\mathrm{bd}}$
\end{tabular}

Note: Means in the same column with different superscripts is differ significantly $(\mathrm{P}<0.05)$

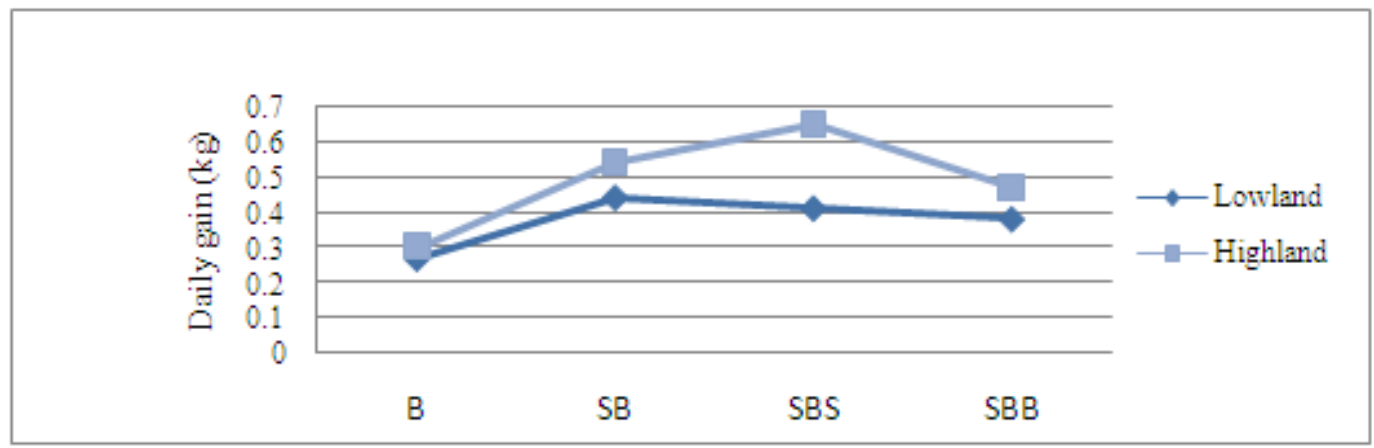

Fig. 2. Post weaning growth response of genotypes on the different altitude

\subsection{Prepubertal growth}

The prepubertal growth rate (GR-1,2) of B calf and crosses (SB, SBS, and SBB) in the lowland and highland environment are provided in Table 4. The B calves had an average GR-1,2 of $0.29 \mathrm{~kg} /$ day which was not influenced by the altitude of farms, however, it was significantly lower than the average of $0.55,0.60$, and 0.52 $\mathrm{kg} / \mathrm{day}$ for SB, SBS, and SBB calves, respectively.

There were an increase in GR-1,2 of the crosses calves from lowland to highland, in which the average GR1,2 of $0.62 \mathrm{~kg} /$ day for the crosses calves in highland were significantly higher than that of $0.48 \mathrm{~kg} / \mathrm{day}$ in the lowland. The SBS calf as a genotype with largest proportion of Simmental tend to grow slowest $(0.42 \mathrm{~kg} / \mathrm{day})$ in the lowland but significantly fastest $(0.73 \mathrm{~kg} /$ day $)$ in the highland environment.

Table 4. Prepubertal growth rate (kg/day) of Bali (B) cattle and its crosses with Simmental (S) breed at different altitude of farms

\begin{tabular}{cccc}
\hline & & \multicolumn{2}{c}{ Prepubertal growth rate (GR-1,2), kg/day } \\
\cline { 2 - 4 } Genotype & Number of animal & $\begin{array}{c}\text { Lowland } \\
(0-100 \mathrm{~m})\end{array}$ & $\begin{array}{c}\text { Highland } \\
(700-1.000 \mathrm{~m})\end{array}$ \\
\hline B & 187 & $0.28 \pm 0.04^{\mathrm{a}}$ & $0.31 \pm 0.05^{\mathrm{a}}$ \\
SB $\left(1 / 2 \mathrm{~B}^{1} / 2 \mathrm{~S}\right)$ & 165 & $0.49 \pm 0.06^{\mathrm{b}}$ & $0.57 \pm 0.11^{\mathrm{c}}$ \\
$\mathrm{SBS}\left(1 / 4 \mathrm{~B}^{3} / \mathrm{S}\right)$ & 217 & $0.42 \pm 0.05^{\mathrm{b}}$ & $0.68 \pm 0.09^{\mathrm{d}}$ \\
SBB $\left(3 / 4 \mathrm{~B}^{1 / 4 \mathrm{~S}}\right.$ & 156 & $0.45 \pm 0.04^{\mathrm{b}}$ & $0.53 \pm 0.06^{\mathrm{c}}$ \\
\hline
\end{tabular}

Note: Means in the same row and column with different superscripts is differ significantly $(\mathrm{P}<0.05)$ 
Prepubertal growth rate of Bali cattle and its crosses with Simmental breed at lowland And ....

\section{Discussion}

The BW, WW.150, and YW were found higher for crosses calves than that of B calves, both in lowland and highland environment. Likewise for GR-1 and GR-2. This indicated that crossing Bali cattle (Bos sondaicus) with Simmental (Bos taurus) has produce offsprings with greater in weight, whether at birth, weaning, or yearling, then, grew more rapidly within the period of prepubertal, compared to the purebred Bali calves. These results are in agreement with previous study [15], and similar to many other studies involving crossbreeding between Bos indicus and Bos taurus in the tropical countries $[9,16,17,18,19,20]$.

However, these preweaning and post weaning performances of the genotypes were different by the altitude of farms, in which the genotypes raised in the highland were found to have higher BW, WW.150, and YW, and grew faster than those of raised in the lowland environment. It suggests that the wide variation in thermal environment between those two different altitudes have a strong effect on the calves and their dams during prenatal and preweaning or on the calves within period from weaning to yearling. The recorded average daily temperature of 31.6 ${ }^{\circ} \mathrm{C}$ for lowland environment exeeded the comfort zone temperature range of $10-27{ }^{\circ} \mathrm{C}$ for tropical cattle breed $[12$, 21], while the $24.5^{\circ} \mathrm{C}$ for highland is within that range. Likewise, the recorded average daily THI of 79.2 for lowland indicated of thermal stress environment for beef cattle breeds, while the 69.4 for highland is consider to safety zone [22]. Thermal environment can have a strong influence on performance of animals [23, 24, 25]. Similarly, altitude of farms has significant effects on the production performance in cattles [26, 27, 20, 28]. In contrast, it has reported that there were no significant differences in milk yield across extreme altitude [29]; however altitude in that study only ranged from 50 to $367 \mathrm{~m}$.

The average BW of $16.91 \mathrm{~kg}$ for B calves in the present study were slightly exceeded the range of 12.30 to $16.80 \mathrm{~kg} \mathrm{BW}$ reported for the breed in the country [30], this because of the calves used in this study derived from selected dam and sire in term of artificial insemination program that has been developed to improve cattle productivity in the country. It was, however, in agreement with $16.46 \mathrm{~kg} \mathrm{BW}$ reported for the breed in the similar farm management [31]. Other indigenous cattles in the tropical countries are reported to have BW $24.14 \mathrm{~kg}$ for Sistani cattle [32], $26.80 \mathrm{~kg}$ for Nguni cattle [18], and $17.35 \mathrm{~kg}$ for Sanga cattle [33]. While the average BW of $28.40 \mathrm{~kg}$ for the crosses calves are within the range of 26.42 to $29.67 \mathrm{~kg} \mathrm{BW}$ reported for the genotypes in West Nusa Tenggara province, the eastern part of Indonesia [34], and was slightly higher than the average of $27.88 \mathrm{~kg}$ BW reported for the genotypes in the similar farm management [31]. It was then, 67.95\% heavier than that of B calf. As a comparison, the Nguni $\mathrm{x}$ Simmental crossbred calf is reported to have only $16.80 \%$ higher BW than the purebred Nguni calf [18].

Besides, the BW was significantly different among genotypes of the crosses calves, in which the genotype with largest proportion of Simmental (SBS) showed the highest BW than those of other genotypes, both in lowland and highland environments. Increasing percentage of BW doe to the crossing were averages 72.66, 93.65, and $41.49 \%$ for SB, SBS, and SBB calves, respectively. In relevance to this results, previous study [17] has reported that crossbreeding between Indonesian local cattle (PO) and Simmental breed took place in Java island increase BW of offsprings by $20.08,37.26$, and 58,40\% for F-1 (50\% Simmental), backcross-1 (75\% Simmental), and backcross-2 (87,5\% Simmental), repectively. This increase might be resulted from both complementary and heterosis advantage of the crossing [35], which was in agreement with the some other findings [36, 37, 38, 39, 20].

Moreover, the crosses calves raised in the lowland were found to have lower BW of $6.20,9.54$ and $6.82 \%$ for SB, SBS, and SBB calves respectively, compared to those raised in the highland environment. This lower BW of lowland calves might be doe to thermal stress experienced by the dams during pregnancy, wherein birth weight is a consequence of the net supply of nutrients reaching the foetus, which is influenced by factors including primarily maternal thermal stress, foetal genotype, and maternal genotype [40, 41]. However, other study in PO x Limousine crossbred conducted in East Java [20,42] reported that no significant effects of altitude of farms on BW of both PO and crossbred calves. Some other factors including the animal itself, farm management, nutritions, and other climatologically aspects might be involved and reasonable on that different result.

The crossing was also increase WW.150 of offsprings by an average 58.97, 67.81, and $41.67 \%$ for SB, SBS, and SBB calves, respectively, compared to the average of $70.96 \mathrm{~kg} \mathrm{WW} .150$ recorded for B calves. Genotype with higher proportion of Simmental had higher increasing index. Therefore, the genotype with highest increasing index was of SBS calf. This indicated that the increase in WW.150 obtained for the crosses calves are derived from Simmental which known superior in this trait, and have high preweaning growth rate that reach an average of 1.8 $\mathrm{kg} /$ day [43]. Moreover, weaning weight is known to be an economical trait with high heritability; its heritability reach 30\% [44]. Increase in weaning weight of offsprings was also suggested to be an advantage of crossing between breeds which much different in such trait $[45,35]$. Other study reported, crossbreeding indigenous Nguni cattle with Simmental breed increase weaning weight 205 of their offsprings by 17.50\% [18]. This was, however, 
Prepubertal growth rate of Bali cattle and its crosses with Simmental breed at lowland And ....

largely lower compared to the average increasing percentage of $56.15 \%$ WW.150 reached by Bali x Simmental crossed calves in the present study. Contrary, crossbred of 50\% Nallore x 50\% Simmental in Brazil is reported to have no significant different of $205 \mathrm{~d}$ weaning weight with the crossbred of $75 \%$ Nallore x $25 \%$ Simmental [46]. The differences may be genetic, since the present study is designed between breeds which have a largely different of productive traits. The Simmental is a heavy beef breed with fast growth rate, compared with the Bali breed which is a lighter breed and slow growth rate.

There were an increase of 7.85, 19.16, 40.70, and 16.15\% WW.150 for B, SB, SBS, and SBB calves, respectively, from lowland to highland environment. It showed that, genotype with higher proportion of Simmental had higher increasing index. The result was in agreement with finding of Siregar et al [27] who reported, that the $205 \mathrm{~d}$ weaning weight of PO x Simmental (PS) crossbred and PS x Simmental (PSS) backrossed in West Sumatera, Indonesia, were higher in highland $(204,5$ and $239,1 \mathrm{~kg})$ than those in lowland environment $(179,8$ and $220,8 \mathrm{~kg})$. Similar result was also reported for $105 \mathrm{~d}$ weaning weight of PO x Limousine crossbred in East Java, Indonesia [20]. This lower WW.150 of the crosses calves in lowland environment might be due to thermal stress experienced by the calves and their dam because of high daily temperature $\left(31.27{ }^{\circ} \mathrm{C}\right)$ and THI $(78.06)$ of the environment. High environmental temperatures may suppress milk production resulting in period of suck which interfere with suckle [47]. Heat stress reduced suckling frequency and shortens suckling period [48], also causes heat transfer from dam to calf when suckling [44].

The crosses calves farmed in the highland were found to have $14.03,56.52$, and $25.33 \%$ higher GR-1 for SB, SBS, and SBB calves respectively, compared to those of farmed in the lowland environment. Genotype with highest proportion of Simmental (SBS calf) had highest increasing index than those of other genotypes. This result was in agreement with findings for PO cattle and its crosses with Simmental [27], likewise for PO and its crosses with Limousine [20]. Whereas, GR-1 of the B calves in the lowland was not significantly different with those in the highland environment. This because of the B cattle is an indigenous cattle breed in the tropic and has been known as a well adaptable breed on the various condition of thermal environment [4].

At yearling, the crosses calves were found in average $87.42 \mathrm{~kg}$ or $66.81 \%$ heavier than B calf. This may due to the much heavier at birth of the crosses than the B calves, since the BW and YW are correlated positives. Level of the correlation was obtained in average of 0.58 , which is within the range of 0.40 to 0.70 recorded for Angus breed based on data from the American Angus Association Sire Evaluation report [49]. Besides, it has reported that sire breed has highly significant effects on yearling body weight of crossbred calves [50,51,33].

The average YW of the calves were $130.85,215.98,246.71$, and $192.12 \mathrm{~kg}$ for B, SB, SBS, and SBB calves, respectively, depend on the altitude of farms. The calves farmed in the highland were found to have 14.08, $16.24,42.00$, and $15.00 \%$ higher YW for B, SB, SBS, and SBB calves respectively, than those of farmed in the lowland environment. This might be due to the more comfortable environment of the highland for the genotypes, wherein the animals have higher feed intake [53,54] and, offcourse higher inergy intake [55], and using less energy for maintenance so then more energy may utilized for productive purposes. It so happen, the average YW of 130.85 $\mathrm{kg}$ for B calf is within the range of YW reported for the breed in the country [30], and slightly higher than $125.62 \mathrm{~kg}$ YW reported for the breed in similar farm management [31]. While the average YW of $218.18 \mathrm{~kg}$ for the crosses calves was lower than $231.27 \mathrm{~kg}$ YW reported for the genotypes in the same province [34].

Further, the averages GR-2 of the genotypes are $0.28,0.47,0.53$, and $0.42 \mathrm{~kg} / \mathrm{day}$ for B, SB, SBS, and SBB calves, respectively. These data point out that, genotype with larger proportion of Simmental grew faster than those of other genotypes. In contrast, genotype with higher proportion of Bali breed grew slower. This because the post weaning growth is a high heritability trait, reached $60 \%[44,56]$. The average of $0.28 \mathrm{~kg} / \mathrm{day}$ GR-2 for B calves was slightly higher than $0.26 \mathrm{~kg} /$ day reported for the breed in the similar farms management [31]. It so happen, the average of $0.47 \mathrm{~kg} /$ day GR-2 for the crosses calves was slightly lower than $0.51 \mathrm{~kg}$ post weaning daily weight gain for the genotypes in the similar farms management [34], but it was closely lower than $1.55 \mathrm{~kg}$ post weaning daily gain reported for Nguni x Simmental crossbred calf [18].

At post weaning, the crosses calves in this study grew in average $69.05 \%$ faster than B calves, depend on the altitude of farms. As a comparison, post weaning growth rate of Nguni x Simmental crossbred calf was 39\% higher than the purebred Nguni calf [18]. The crosses calves farmed in the highland were found to have 15.24, 42.00, and $14.55 \%$ higher GR-1 for SB, SBS, and SBB calves respectively, compared to those of farmed in the lowland environmrnt. Genotype with highest proportion of Simmental (SBS calf) had highest increasing index than the others. This result was in agreement with findings for PO cattle and its crosses with Simmental [27], likewise for PO and its crosses with Limousine [20]. Whereas, GR-2 of the B calves in the lowland was not significantly different with those in the highland environment. This because of the B cattle is an indigenous cattle breed in the tropic and has been known as a well adaptable breed on the varied condition of thermal environment [4]. 
Prepubertal growth rate of Bali cattle and its crosses with Simmental breed at lowland And ....

Prepubertal growth rates (GR-1,2) of the calf were then significantly different between B calves and the crosses, and between the two altitudes of farms for the crosses calves (Table 4). The B calves were found to have an average of $0.29 \mathrm{~kg} /$ day GR-1,2 which was not different between farmed in the lowland and highland environment. This agrees with the results of previous study carried out at various location of cattle farms in Indonesia [27, 20, 31, 42]. While for the crosses were found to have in average $0.53,0.56$, and $0.52 \mathrm{~kg} / \mathrm{day}$ GR-1,2 for SB, SBS, and SBB calves, respectively, which have no significant different each other.

During prepubertal, thereby, the crosses calves grew in average $81.84 \%$ faster than B calf, which was 75.02, 60.71, and 82.14\% faster than B calf in the lowland for SB, SBS, and SBB calves, respectively, and 83.55, 115.48, and 70.97\% faster than B calf in the highland for SB, SBS, and SBB calves, respectively. These of growth increasing index indicated that, SBS calf as a genotype with highest proportion of Simmental grew slowest in the lowland but it was fastest in the highland environment, compared to those other genotypes of crosses (SB and SBB) calves.

\section{Conclusion}

Crossing of Bali cattle with Simmental indicated the higher proportion of Simmental in highland environment $(\mathrm{THI}<70)$ was better on prepubertal growth rate of crosses calves than those of indicated higher proportion of Bali breed. Whereas in the lowland (THI >70<80), crosses calves with higher proportion of Bali breed was better on prepubertal growth rate to those of indicated higher proportion of Simmental.

\section{Refferences}

[1]. H Bazzi and M. Alipanah, The effects of some environment factors on the weaning weight of Sistani beef calves. J. Anim. and Vet. Advances, 10(11), 2011, 1480-1483

[2]. Zulkharnaim, Jakaria, and R. R. Noor. Identification of genetic diversity of growth hormone receptor (GHR/Alu I) gene in Bali cattle. Media Peternakan, (33), 2010, 81-87

[3]. S R A Bugiwati, Body dimension growth of Bali calf in South Sulawesi. J. Sci. and Tech. (7), 2007, 103-108 (Article in Indonesian with an English abstract)

[4]. K. Entwistle and D.R. Lindsay, Strategies to improve Bali cattle in Eastern Indonesia. ACIAR proc., (110), 2003, 1-2

[5]. R R Noor, A. Farajallah, and M. Karmita, The purity test of Bali cattle by haemoglobin analysis using the isoelectric focusing method. J.Hayati, (8), 2011, 107-111

[6]. K Diwyanto and I. Inounu, The impact of crossbreeding on productive performance of beef cattle. Wartazoa, 19(2), 2009, 93-102 (Article in Indonesian with an English abstract)

[7]. G Tang, J. Stewart, G. Plastow, S. Moore, and Z. Wang, Optimizing a beef production system using specialized sire and dam lines. Can.J.Anim.Sci, (91), 2011, 353-361

[8]. H Dadi, G. F. Jordan, S. J. Schoeman, and J. van der Westhuizen, The effect of Charolis and Hereford sires and stright bred and crossbred dams on pre weaning growth of calves. South African J. of Anim. Sci. 32(1), 2002, 38-43

[9]. C McCool, Buffalo and Bali cattle - their reproductive behavior and Physiology. Trop.Anim.Healt Prod., (24), 1992, 165

[10]. $\quad$ N T Yeates, P.J. Schmidt, and J.S. Young, Beef cattle production. (Butter worths Pty. Limited, Brisbane, 1975)

[11]. Soeharsono, Fisiologi dan bionomika ternak (Padjadjaran University press, Bandung, Indonesia 1998), (Text book in Indonesian)

[12]. G. Williamson and W.J.A. Payne, An introduction to animal husbandry in the tropics (Tata McGrow-Hill Pub. Co.Ltd., New Delhi, India, 1980)

[13]. B. Lakitan, Dasar-Dasar Klimatologi. Cet. ke-2 (Raja Grafindo Persada, Jakarta, 2002) (Text book in Indonesian)

[14]. K Meyer, Variance components due to direct and maternal effects for growth Traits of Australian beef cattle. Livest. Prod. Sci. (31), 1992, 179-204

[15]. M Ashari, W. Busono, Nuryadi, and A. Nurgiatiningsih, Analysis of chromosome and karyotype in Bali cattle and Simmental-Bali (Simbal) crossbred. Pak.J.Biol.Sci., 15(15), 2012, 736-741

[16]. A Ozluturk, M. Yanar, N. Tuzemen, dan S. Copuzlu. Calving and preweaning growth performance traits of calves sired by Charolis, Simmental, and Eastern Anatolian Red bulls. Turk J. Vet. Anim. Sci., (30), 2006, 257-263

[17]. P.P. Putro, Impact of crossbreeding on productivity of cows and progenies. Proc. workshop on crossbreeding of beef cattle in Indonesia, Lustrum 8th Animal Husbandry Faculty, Gajah Mada University, August $8^{\text {th }} 2009$ (Article in Indonesian with an English abstract)

[18]. M M Scholtz and A.Teunissen, The use of indigenous cattle in terminal crossbreeding to improve beef cattle production in Sub-Saharan Africa. Anim. Gen. Resources. (46), 2010, 33-39

[19]. E Casas, R.M. Thallman, and L.V. Cundiff, Birth and weaning traits in crossbred cattle from Hereford, Angus, Brahman, Boran, Tuli, and Belgian Blue sires. J. Anim.Sci. 89(4), 2011, 979-987

[20]. H. Nugroho, The productivity of Peranakan Ongole (PO) cattle and its crossbred with Limousine breed under smallholder farms at different altitudes area, Doctoral diss., Post Graduate Program of Animal Science Faculty, Brawijaya University, Malang, Indonesia, 2012.

[21]. R. S. Copland, The environment of sheep and goat. In: T.N. Edey (ed.), A course manual in tropical sheep and goat production, (Canberra: Australian Universities International Development Program-AUIDP, 1993)

[22]. C. R. Dahlen, and C. L. Stoltenow, Dealing with heat stress in beef cattle operation, NDSU Extension Service, Dakota State University, Fargo, 2012

[23]. G L Hahn, Dinamic responses of cattle to thermal heat load. J.Anim.Sci. 77(suppl. 2/J), 1999, 10-20

[24]. J B Gauhan, T.L. Mader, S.M. Holt, G.L. Hahn, and B.A. Young, Review of current assessment of cattle and microclimate during period of high heat load. Anim.Prod.Aus. (25), 2002, 69-72 
[25]. D T Beatty, A. Barnes, E. Taylor, and S.K. Maloney. Physiological responses of Bos taurus cattle to prolonged continous heat and humidity. J. Anim.Sci. (84), 2006, 972-985

[26]. R E Christen, P.L. Kunz, W. Langhans, H. Leuenberger, F. Sutter, and M. Krewzer. Productivity, requirements and efficiency of feed and nitrogen utilization of grass-fed cows exposed to high Alpine conditions. J.Anim.Physiol.Anim.Nutr. (76), 1996, 22-35

[27]. A R Siregar, J. Bestart, R.H. Matondang, Y. Sani, dan H. Panjaitan. The determination of breeding system for beef cattles in West Sumatera province, Indonesia. Proc. Sem. Nas. Pet. dan Vet., BP Vet., Bogor, 2001, 113-121 (Article in Indonesian with an English abstract)

[28]. J L Williams, J.K. Bertrand, dan M. Lukaszewicz. Genotipe by environment interaction for growth due to altitude in united states angus cattle. J. Anim. Sci. (90), 2012, 2152-2158

[29]. J R. Bryant, N. Lopez-Villalobos, J.E. Pryce, C.W. Holmes, D.L. Johnson, and D.J. Garryc. Environment sensitivity in New Zealand dairy cattle. J. Dairy Sci. (90), 2007, 1538-1547

[30]. C. Talib, K. Enstwistle, A. Siregar, S. Budiarti, and D. Lindsay, Survey of population and production dynamics of Bali cattle and existing breeding programs in Indonesia. ACIAR Proc., (110), 2003, 3-8

[31]. M. Ashari, Analysis of production performance, reproductive efficiency, and chromosome of Bali cattle and its crossbred with Simmental cattle, Doctoral diss., Doctoral diss., Post graduate program of animal science faculty, Brawijaya University, Malang, Indonesia, 2012.

[32]. H Bazzi, Evaluation of non-genetic factors affecting birth weight in Sistani cattle. J. Anim.Vet.Advances. 10(23), 2011, 3095-3099

[33]. F Y Obese, D. A Acheampong, dan K. A. Darfour-Oduro, Growth and Reproductive Traits of Friesien x Sanga Crossbred Cattle in the Accra Plais of Ghana. Afr. J. Food Agric. Nutrition Dev. 13(2), 2013, 7362-7371

[34]. A S Dradjat, An evaluation on one-fourth century of artificial insemination program for cattles in Eastern Indonesia. J. Anim.Sci.Tech. 5(2), 2002, 121-128 (Article in Indonesian with an English abstract)

[35]. S. Plank, J. Parish, dan T. Smith, Crossbreeding system for beef cattle, MSU extension service, Missisippi State University, 2013

[36]. W W Ellis, B. Sibbit, and J. F. Lasley, Effect of mating system on weaning traits in beef cattle. J. Anim. Sci., (48), 1979, 7-12

[37]. R E Short, M. D. MacNeil, M. D. Grosz, D. E. Gerrad, dan E. E. Grings. Pleotropic effect in Hereford, Limousin, and Piedmontese F2 crossbred calves. J. Anim. Sci. (80), 2002, 1-11

[38]. R. H. Gary, Crossbreeding system in beef cattle, IFAS extension service, University of Florida, 2007

[39]. P. Scott, Cross breeding in beef cattle. Virginia Cooperative Extension, Virginia State University, (14), 2009, 45-68

[40]. M D Holland and K.G. Odde, Factors affecting calf birth weight: a review. Theriogenology, (38), 1992, 769-798

[41]. P L Greenwood, L.M. Café, D.W. Hannessy, and H. Hearnshaw, Consequences of nutrition and growth retardation early in life for growth and composition of cattle and eating quality of beef, Recent Adv. Anim. Nutr. Australia, (15), 2005, 183-195

[42]. S Suyadi, L. Hakim, S. Wahjuningsih, and H. Nugroho, Reproductive performance of Peranakan Ongole (PO) and Limousin x PO crossbred (Limpo) cattle at different altitude areas in East Java, Indonesia. J.Appl.Sci.Agric., 9(11), 2013, 81-85

[43]. L A Kuehn, and R. M. Thallman, Mean EPD's report by different breed. Proc. Beef improvement federation $44^{\text {th }}$ research symposium an annual meeting. April $18-21^{\text {st }}, 2012,147-151$

[44]. M E Ensminger, Beef Cattle Science, Anim. Agric. Series. Danville, (Illinois: The Interstate Printers ad Pub. Inc., 1986)

[45]. H Bazzi, and M. Ghazaghi, The effects of some environment factors on the birth weight of Sistani beef calves. J. Anim. and Vet. Advances, 10(22), 2011, 2240-2243

[46]. C.A.S.D. Muniz, L. C. Pelicioni, dan S. A. Quciroz, Weaning weight, preweaning average daily gain and age at first calving performance evaluation of Nallore and Crossbred in West Brazil. Proc. 6th World Congress on Genetic Applied to Livestock Production, Armidale, (23), 2000, 544-556

[47]. D Manalu, A. Sudono, and B.P. Purwanto, Heat stress in cattle and the effect of shade on production and behaviour: a review. J. Experimental Agric. (34), 2003, 285-295

[48]. M Makkin, The estimation of energy requirement for thermoregulation in Frisien Holstain cows. J. Pet.Indo. 11(2), 2002, 223-229 (Article in Indonesian with an English abstract)

[49]. N. L. Buchram, and M.G. Thomas. A comparison of birth weight and yearling weight along with cow efficiency. Proc. Corona Range and Livestock Research Center, 2007, 122-128

[50]. G W Rahnefeld, G. M. Weiss, H. T. Fredeen, J. E. Lawson, dan J. A. Newman, Genetic Effects on Postweaning Growth of Three-Way Cross Beef Cattle. Can.J.Anim.Sci. (68), 1988, 647-654

[51]. D D Lunstra and L.V. Cundiff, Growth and prepubertal development in Brahman-, Tuli-, Belgian Blue-, Hereford-, and Angus-sire F1 bulls. J. Anim.Sci. (81), 2003, 1414-1426

[52]. M. Vermorel, Effects of climatic conditions on energy metabolism and performance of calves. in: M.W.A. Verstegen and A.M.Hanken (Eds.), Energy metabolism in farm animals. (Dordrecht, Boston: Martinus Nijhoff Pub., 1987), 180-198

[53]. J. Le Dividich, P. Herpin, P.A. Geraert, and M. Fermorel, Cold stress. In: C Phillips and D. Piggins (Eds), Farm animals and the environment, (UK: C.A.B. Intr., 1992), 3-26

[54]. Z C Lymo, R. Nkya, L. Schoonman, and F.J.C.M. van Eirdenburg . Postpartum reproductive performance of crossbred Dairy Cattle on Smallholder Farms in Sub-humid Coastal Tanzania. J.Trop.Anim.Healt Prod. (36), 2004, 269-279 